\title{
Trematodes in a Cyathura carinata population from a temperate intertidal estuary: infection patterns and impact on host
}

\author{
K. Thomas Jensen $*^{\ddagger}$, Susana M. Ferreira ${ }^{\dagger}$ and Miguel A. Pardal ${ }^{\dagger}$ \\ *Department of Marine Ecology, Institute of Biological Sciences, University of Aarhus, Finlandsgade 14, \\ DK-8200 Aarhus N, Denmark. 'IMAR - Institute of Marine Research, Department of Zoology, University of Coimbra, \\ 3004-517 Coimbra, Portugal. ${ }^{\ddagger}$ Corresponding author, e-mail: kthomas@ biology.au.dk.
}

A study was initiated to identify trematode patterns in Cyathura from two key sites in the Mondego Estuary: a Zostera-bed and a sandflat. The two subpopulations of Cyathura differ, as the annual recruitment success is much higher and more regular on the sandflat than on the Zostera-bed.

Counting and sizing of trematode cysts inside the body of preserved Cyathura specimens enabled a description of trematode patterns in space and time. Further identification of trematodes was based on DNA studies of unpreserved cysts as well as on identification of parasites in co-occurring mud snails. Two trematode species dominated in Cyathura: Maritrema subdolum (cysts around $190 \mu \mathrm{m}$ ) and a hitherto unknown Levinseniella species (cysts around $340 \mu \mathrm{m}$ ), the latter being the most frequent one. Generally, the prevalence of both species peaked during winter months, when migratory water birds occur in the estuary. Cyathura from the Zostera bed harboured more infections per specimen than those from the sand flat. A much higher density of mud snails $\geqslant 2 \mathrm{~mm}$ (which can be host to microphallids) and a low abundance of Cyathura are thought to be the main reasons for this pattern. Field data did indicate a host size-dependent maximum number of cysts in Cyathura that could be a result of enhanced mortality at high cyst intensities. Furthermore, parasites were underrepresented among ovigerous Cyathura specimens, suggesting a negative impact on gametogenesis. As a consequence, microphallid trematodes may be a critical factor controlling recruitment strength in Cyathura, especially at the Zostera-site.

\section{INTRODUCTION}

In brackish water ecosystems, such as estuaries and shallow water lagoons, where numerous fish and birds congregate, digenean trematodes are widespread among macrozoobenthic organisms that are intermediate hosts to parasites using the vertebrates as their definitive hosts. As such macroparasites may have considerable impact on host populations (see Mouritsen \& Poulin, 2002), environmental studies focusing on abundance patterns of invertebrates should include parasites as a possible determining factor. Descriptions of spatio-temporal patterns and identification of processes controlling the dynamics of digeneans are furthermore essential for improving our understanding of their importance in ecosystems. In a long-term study on distribution and dynamics of dominant benthic species, the Mondego Estuary (Portugal) has been used as a model system (Cardoso et al., 2002). Like other estuaries, this system is dominated by a few species (Marques et al., 2002). Among these are the mud snail Hydrobia ulvae (Pennant, 1777) and the isopod Cyathura carinata (Krøyer, 1847), which have been used as target species in several studies (Marques et al., 1994; Lillebø et al., 1999; Cardoso et al., 2002). The present ecosystem accommodates an abundant avifauna, with waders being a predominant group during winter (Lopes et al., 2002). Together these faunal components predetermine that parasites can be abundant in the system because mud snails are known to host several species of digenean trematodes utilizing benthic peracarid crustaceans (amphipods and isopods) as second intermediate hosts and birds as their definitive hosts (Deblock, 1980). So far, only scattered information on parasites in Cyathura has been published (Reimer, 1963; Schulenburg et al., 1999). The purpose of the present study is to provide a description of the temporal pattern in prevalence and intensity of trematode species in Cyathura from two type localities in a southern European intertidal estuary, which is a wintering area to waders. We attempt to identify key processes determining the flux of parasites through the Cyathura population and discuss possible consequences of parasitism to the host population.

\section{MATERIALS AND METHODS}

\section{Study site and sampling programme}

The Mondego Estuary is a small temperate intertidal estuary (1072 ha of wetland habitats) located on the Atlantic coast of Portugal $\left(40^{\circ} 08^{\prime} \mathrm{N} 8^{\circ} 50^{\prime} \mathrm{W}\right.$ ) (Figure 1 in Cardoso et al. (2002)). During the last two decades it has been the subject of a long-term environmental study. Two sites have been monitored in particular: (1) a Zostera noltiibed and (2) a sandflat ('eutrophicated area', Figure 1 in Cardoso et al. (2002)). From the mid-1980s until 1997 the extent of the Zostera-bed declined from 15 ha to 0.02 ha. The sandflat is seasonally covered by green macroalgae, especially Enteromorpha sp. (Cardoso et al., 2002). The 


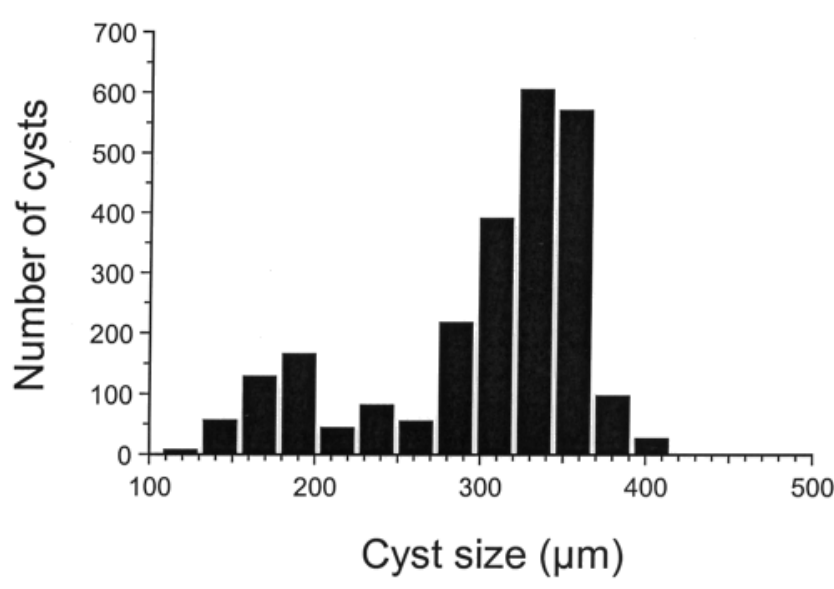

Figure 1. Size distribution (diameter) of all microphallid cysts collected from Cyathura from the two study sites in Mondego Estuary.

substratum at the two sites differ with respect to median grain size (Zostera: 74 to $105 \mu \mathrm{m}$ vs sandflat: 116 to $144 \mu \mathrm{m}$, seasonal variation) (Lillebø, 1996) and content of organic matter (Zostera: $6.8 \% \pm 1.0$ vs sandflat: $3.7 \% \pm 1.0(\overline{\mathrm{x}} \pm \mathrm{SD})$ (Cardoso et al., 2002). Higher salinity values were registered in low water pools at the Zostera plot $\left(20-30 \mathrm{gl}^{-1}\right)$ than at the sandflat plot $\left(20-30 \mathrm{~g} \mathrm{l}^{-1}\right)$. Water temperature in low water pools at the study sites showed an annual range from 8 to $32^{\circ} \mathrm{C}$. Sampling was performed from January 1993 to September 1995, until mid-1994 with fortnightly intervals and monthly thereafter. On each site, 6 to 10 cores $(13.5 \mathrm{~cm}$ diameter) were sampled to a depth of $20 \mathrm{~cm}$, sieved through a $0.5 \mathrm{~mm}$ mesh and preserved in $4 \%$ buffered formalin. Later, animals were separated and kept in 70\% ethanol.

Data on the abundance of waders were provided by Múrias et al. (1997) and Lopes et al. (2002).

\section{Laboratory procedures}

Specimens of Cyathura were counted, measured for cephalic length and sexed. Total body length $(\mathrm{mm})$ of each individual was determined from cephalic length ( $\mathrm{mm})$ using the equation: total body length= $0.7451+9.0101 \times$ cephalic length, $\quad\left(r^{2}=0.97, \quad \mathrm{~N}=115\right)$ (Marques et al., 1994). Cyathura has a two year life-span in the Mondego Estuary and it reproduces once a year. Cohorts were distinguished from each other if overlapping through a modal analysis following the method described by Marques et al. (1994).

All sampled Cyathura individuals were inspected for trematode cysts located inside their abdomen. These cysts were removed, counted and measured. Three different methods have been applied for identifying the trematodes in Cyathura: (1) As mud snails typically will be the first intermediate host to digeneans occurring in Cyathura, snails collected from the Mondego Estuary in 2000 and 2001 were screened for infections. Snails were incubated individually in a small Petri dish under artificial light at temperatures of $20-24^{\circ} \mathrm{C}$ to stimulate shedding of cercariae from the infected snails. Cercariae were identified under a light microscope according to Deblock
(1980); (2) DNA was extracted from cysts sampled from viable Cyathura specimens collected in the Mondego Estuary and from microphallid cercariae harvested from infected snails. Polymerase chain reaction of the internal transcribed spacer (ITS)-regions of rDNA was sequenced and aligned with sequences of known microphallid species to verify identifications based on morphological examinations (Warberg, 2003); (3) Cysts of unknown microphallids were heated to $38^{\circ} \mathrm{C}$ and incubated in trypsin to stimulate excystment (Rebecq, 1964). Morphometric characteristics of excysted specimens were measured and compared with reported descriptions of known species (Warberg, 2003).

Hydrobia snails were counted and measured. Shell height $(\mathrm{mm})$ was determined by measuring maximum shell width $(\mathrm{mm})$ and using the equation: maximum width= $0.4369 \times$ total height $+0.2091 \quad\left(r^{2}=0.97, \mathrm{~N}=339\right) \quad($ Lillebø et al., 1999; Cardoso et al., 2002).

\section{Statistical analysis}

Statistical analyses were performed using the MINITAB 10.2 and the Statistical Package for the Social Sciences version 10 software packages. All data were inspected for violation of required assumptions and, if so, proper transformations or non-pararametric tests were used.

\section{RESULTS}

Trematodes

The size-frequency of microphallid cysts registered in Cyathura indicates that two size-groups were dominant: one with a cyst diameter of $180-190 \mu \mathrm{m}$ and another of 330-360 $\mu \mathrm{m}$ (Figure 1). These modes represent the final sizes attained by mature cysts of some microphallid species. As they grow for up to six weeks within their host before reaching these sizes (maturation time depends on species and temperature) (Galaktionov et al., 1997; Damsgaard, 2002), a high fraction of the cysts with sizes below the peaks probably represent immature cysts of the two dominant species groups. Identification of microphallid species cannot alone be based on mature cyst dimensions, but the smaller size-group $(180-190 \mu \mathrm{m})$ fits with the size of Microphallus claviformis (Brandes, 1888) or Maritrema subdolum Jaegerskioeld, 1909, whereas the larger cysts belong to a hitherto unknown Levinseniella species (Warberg, 2003). Screening of a few thousand Hydrobia specimens from the Mondego Estuary in 2002 resulted in 60 microphallid shedding snails. Of these 53 snails were infected with $M$. subdolum, 2 with $M$. claviformis and 5 with the unknown Levinseniella sp. Therefore, it is reasonable to assume that a major fraction of the small cysts belong to $M$. subdolum. DNA-sequence analyses (ITS2sequence data) have further verified that the small spherical cysts in Cyathura were identical to M. subdolum (unpublished data). Cercariae of the new Levinseniella species exhibit behaviour and morphology similar to what is reported for Cercaria camarquensis (Deblock, 1980), except its lack of tail (Warberg, 2003). The cercaria moves in a leech-like fashion. Both infection experiments and ITS2 sequencing have verified the identity between the large cysts found in Cyathura and the cercariae larvae found in Hydrobia (Warberg, 2003). For the analysis of parasite 

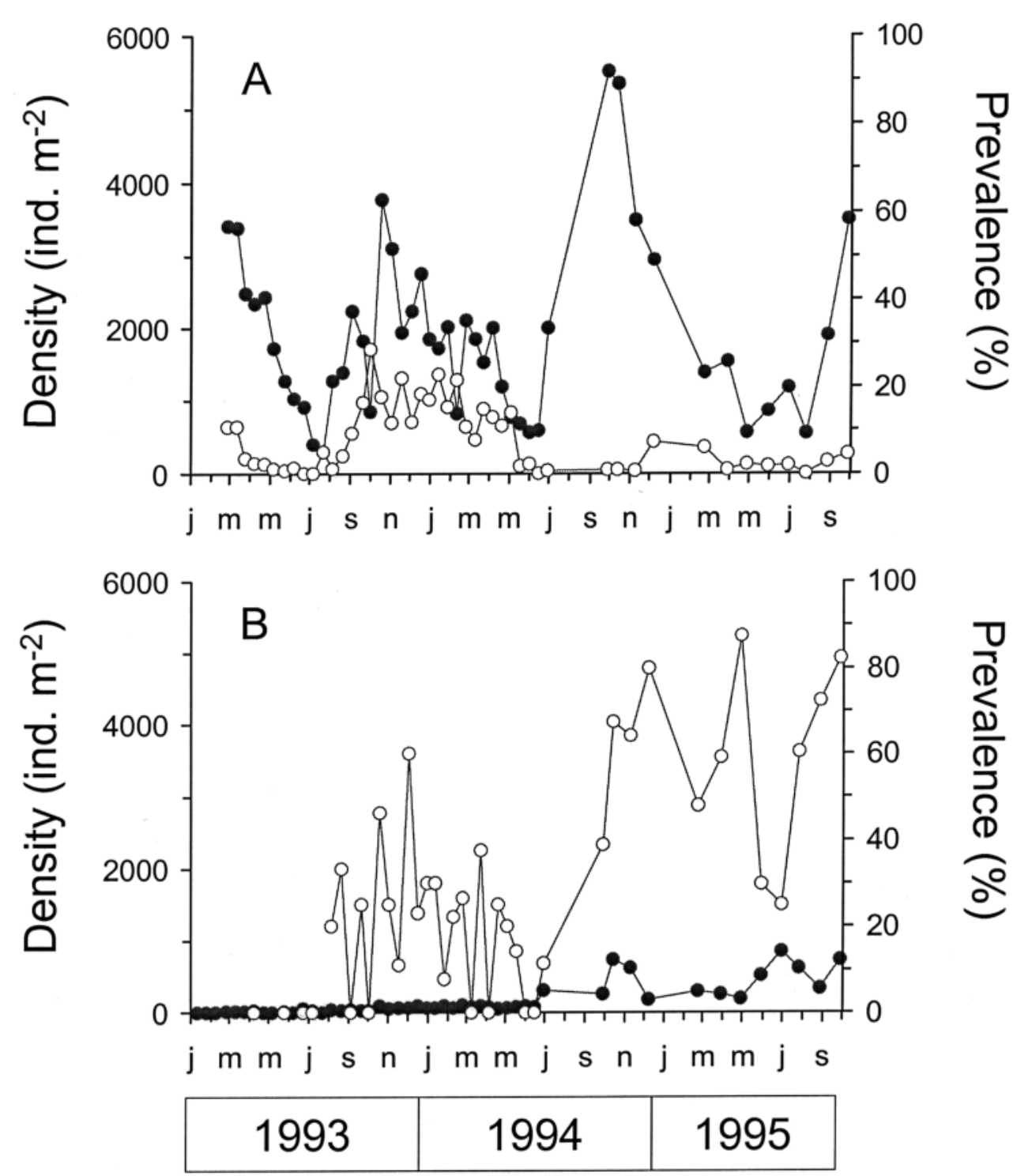

Figure 2. Temporal variation in density $(\bullet)$ of Cyathura $\left(\right.$ ind $\mathrm{m}^{-2}$ ) and prevalence (percentage infected) $(\bullet)$ in the isopod from (A) the sandflat-site and (B) from the Zostera-site.

patterns in Cyathura we will for convenience distinguish between two groups of cysts: (1) $<250 \mu \mathrm{m}$ and (2) $\geqslant 250 \mu \mathrm{m}$. As indicated, a majority of cysts within these groups belong to $M$. subdolum and the unknown Levinseniella, respectively.

Temporal and spatial variation in density and infections of Cyathura Sandflat site

The temporal density variation of Cyathura reflects the annual pattern of reproduction and recruitment (Figure 2A). Ovigerous females had their peak occurrence mid-May to mid-June. From mid-July and onwards, there was a steep increase in density due to recruitment, resulting in peak numbers in October. Afterwards, there was a more gradual decline until the following summer. Generally, infected specimens constituted a minor fraction of the whole population, during most of the study period (Figure 2A). However, from autumn 1993 until summer 1994, up to $30 \%$ of the 1993 year-class was infected. The prevalence increased from August until October and remained at the same level until the die-off of most of the 1993 year-class. In this period, there was a positive correlation between the numbers of uninfected and infected specimens $(\mathrm{r}=0.815, P<0.001, \mathrm{~N}=23$, Pearson correlation coefficient). The development of infections in the 1994 year-class was different, as there was no increase in prevalence before November and only 7\% (December 1994) of this cohort became infected.

The intensity pattern for the 1994 year-class did not show much seasonal variation. The median values were less than 2 cysts for both microphallid species, but a few specimens with more than 10 large cysts $(250 \mathrm{~m})$ were found in the winter months. Overall $66 \%$ of the specimens infected with large cysts had only 1 cyst and less than $1 \%$ of the infected had more than 10. For small cysts, infected isopods accommodated less than 5 cysts each.

\section{Zostera-site}

Until late June 1994, the density of Cyathura was less than 100 ind $\mathrm{m}^{-2}$ (Figure 2B). At this time, the 1994 year-class 

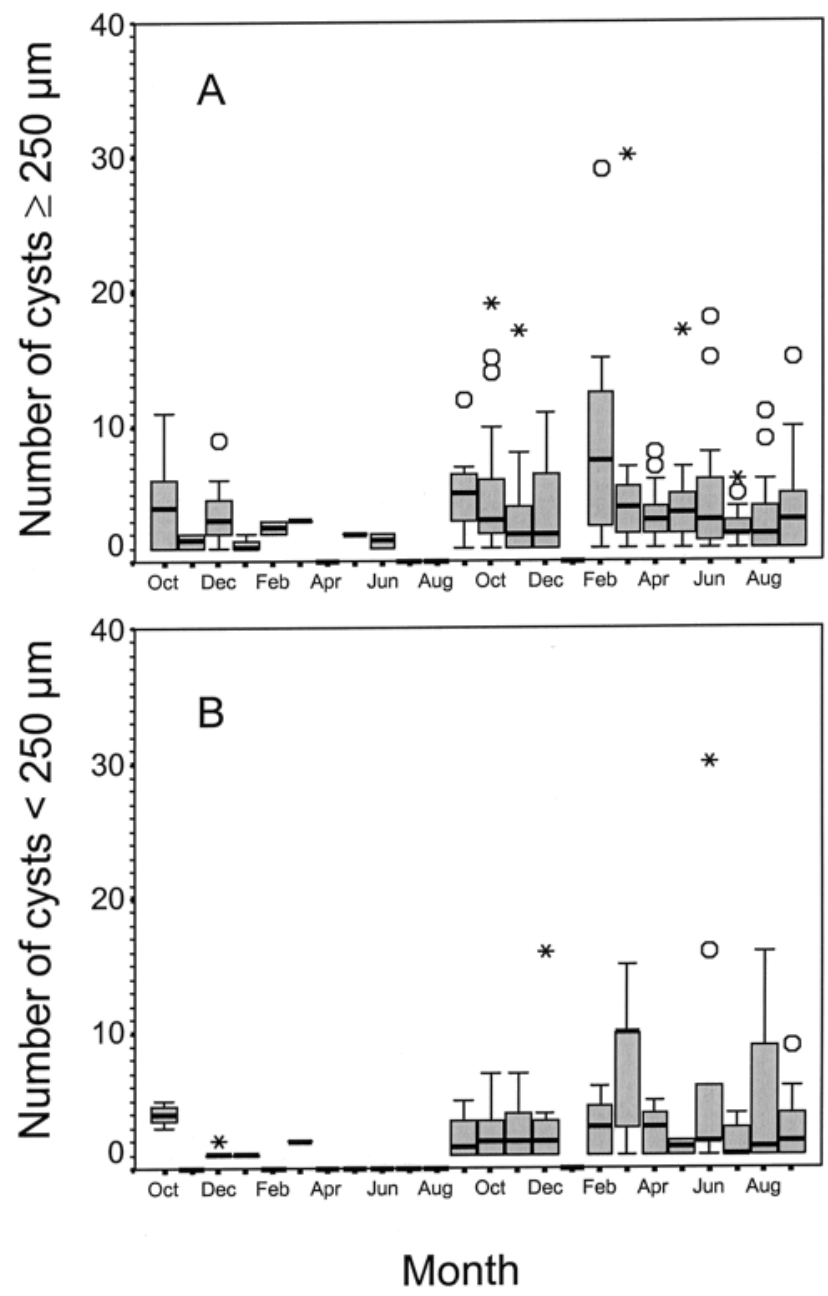

Figure 3. Boxplot of cyst numbers in Cyathura from the Zostera-site from October 1993 until September 1995. (A) Cysts $\geqslant 250 \mu \mathrm{m}$, (B) cysts $<250 \mu \mathrm{m}$. Boxplots show the median, interquartile range, outliers and extreme cases of individual variables (vertical line: is drawn from the upper quartile to the most extreme point that is within a distance of 1.5 of the upper quartile; outliers: values between 1.5 and 3 box length; extremes: values more than 3 box lengths; box length: interquartile length).

recruited and a peak density of 738 ind $\mathrm{m}^{-2}$ was reached in October that declined within a month to a few hundred individuals. Again there was recruitment in 1995 resulting in a small density peak. Basically, the recruitment pattern of Cyathura at the Zostera-bed showed similarity to the pattern at the sandflat-site, but the peak density of recruits was much lower.

The prevalence of microphallid cysts in Cyathura from the Zostera stock was lowest during summer (June-July 1994 and 1995) and highest during winter months (Figure 2B). As a reflection of the low density and thus small sample sizes of Cyathura until mid-1994, the prevalence of cysts fluctuated widely (between 0 and 50\%). The prevalence in the 1994 year-class of Cyathura increased during autumn 1994, in contrast to what happened on the sandflat, and reached high levels from October 1994 until May 1995 (between 40 and 90\%). A major decline took
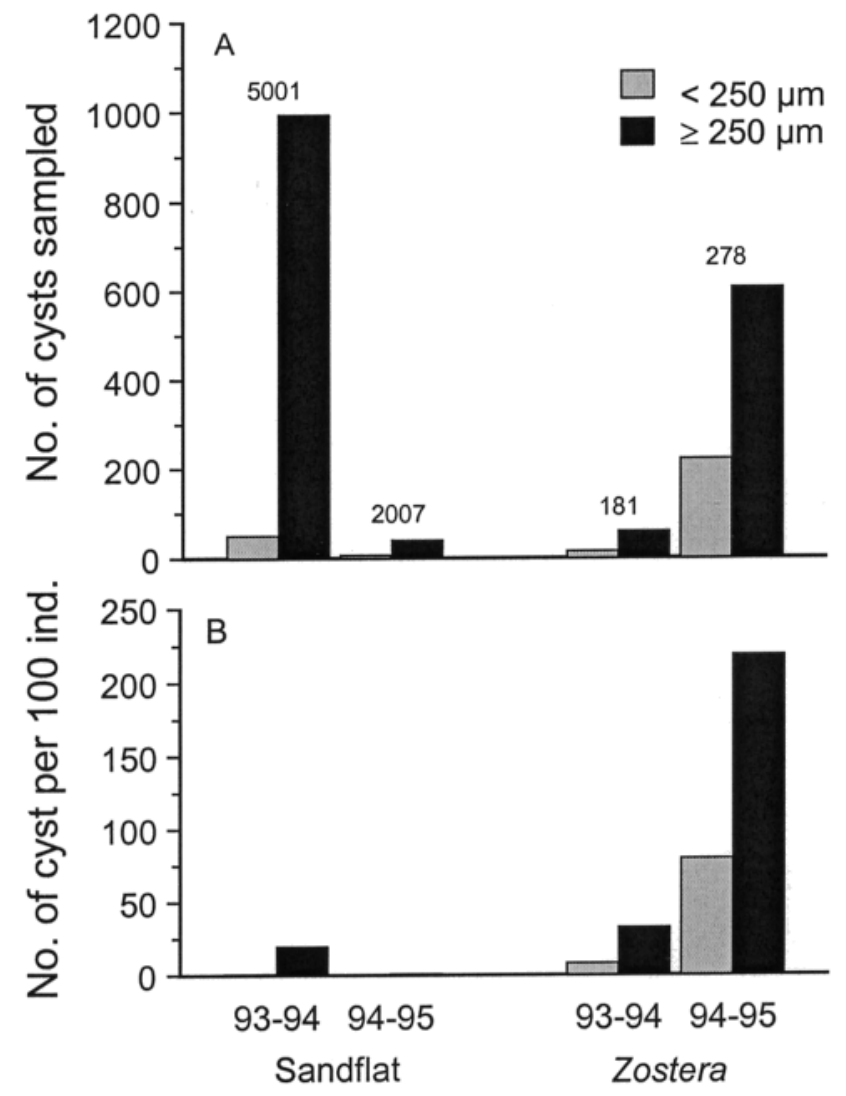

Figure 4. (A) Total numbers of small cysts $(<250 \mu \mathrm{m}$; grey fill) and large cysts $(\geqslant 250 \mu \mathrm{m}$; black fill) recorded from Cyathura in the period June 1993 to May 1994 (93-94) and June 1995 to May 1995 (94-95) from the two study sites in Mondego Estuary. The figures above the columns indicate the number of Cyathura examined; (B) numbers of cysts per 100 specimens of Cyathura calculated from the data shown in Fig. 4A.

place when the 1995 year-class substituted the 1994 yearclass, in summer 1995.

Concerning the development in intensity of trematode cysts in Cyathura, there was a weak seasonal pattern for the most abundant cysts $(\geqslant 250 \mu \mathrm{m})$ in 1994-1995. They had a peak in median intensity in February 1995 (Figure 3A). At this time $25 \%$ of the infected Cyathura stock harboured between 6 and 12 large cysts per specimen. It is obvious, that the distribution of cysts in the host population is aggregated. Up to 30 cysts $(\geqslant 250 \mu \mathrm{m})$ were observed in a single specimen in March 1995. The small and less frequent cysts did not show a pronounced pattern, though the highest median numbers were registered in March 1995. A single individual contained 32 small cysts (Figure 3B).

\section{Overall distribution of cysts in Cyathura}

In total, 1995 cysts have been collected from sampled Cyathura specimens between June 1993 and May 1995. Of these, $52.3 \%$ came from the sandflat stock of Cyathura, in the period from June 1993 to May 1994, whereas 41.6\% were collected from the Zostera stock from June 1994 to May 1995 (Figure 4A). However, the number of Cyathura 


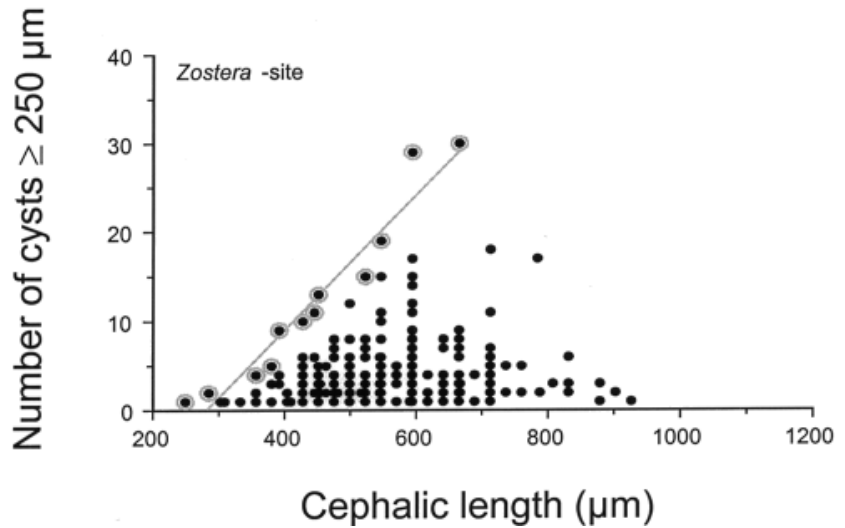

Figure 5. Numbers of cysts $(\geqslant 250 \mu \mathrm{m})$ as a function of cephalic length of Cyathura from the Zostera-site. Maximum cyst numbers of each length group are indicated by black symbols enclosed in an open circle. (For each cephalic length a maximum cyst number was chosen if it exceeded the preceding values.) A line is fitted to the data points indicating maximum cyst numbers.

collected from the Zostera site in 1994-1995 accounted only for $3.7 \%$ of all specimens sampled, whereas those from the sandflat (1993-1994) accounted for 67\%. To facilitate comparison in space and time across host density, the numbers of microphallid cysts per 100 specimens of Cyathura have been calculated (Figure 4B). From this graph it appears that cysts $\geqslant 250 \mu \mathrm{m}$ are more frequent than those $<250 \mu \mathrm{m}$. It is also obvious that the Zostera stock of Cyathura accommodated more cysts per host specimen in the period from June 1994 to May 1995 than in the previous year, but it harboured also more cysts per specimen than Cyathura from the sandflat in both years.

\section{Trematode infections in relation to host size and ovigerous females}

The number of cysts in Cyathura (data from the Zosterasite) shows a clear size-dependent maximum intensity $(\geqslant 250 \mu \mathrm{m})$ until a host length of $7 \mathrm{~mm}$ (cephalic length $700 \mu \mathrm{m}$ ) (Figure 5). Up to this threshold, there is a linear relationship between the maximum cyst number (MCN) for each size-group and cephalic length (CeL) $\left(\mathrm{MCN}=0.076 * \mathrm{CeL}-21.165 ; \mathrm{r}^{2}=0.93\right)$. (For each CeLinterval a MCN was chosen if it exceeded the preceding values.) Using the slope of this formula, it appears that an increase in $\mathrm{CeL}$ of $200 \mu \mathrm{m}$ (corresponding to an increase in body length of $2 \mathrm{~mm}$ ) enhances MCN with about 15 cysts.

Cysts were very rarely observed in ovigerous females or in females with brood pouches (Figure 6). During the three reproductive seasons (defined by the presence of females with brood pouches) 4066 females were collected. Of these 15\% (609 individuals) had brood pouches with or without eggs. Among the females without brood pouches $8.5 \%$ (295 individuals) were infected, whereas only $0.5 \%$ (2 individuals) of those with brood pouches had infections. This difference was highly significant $\left(\chi^{2}=51.5, P=0.000\right)$.

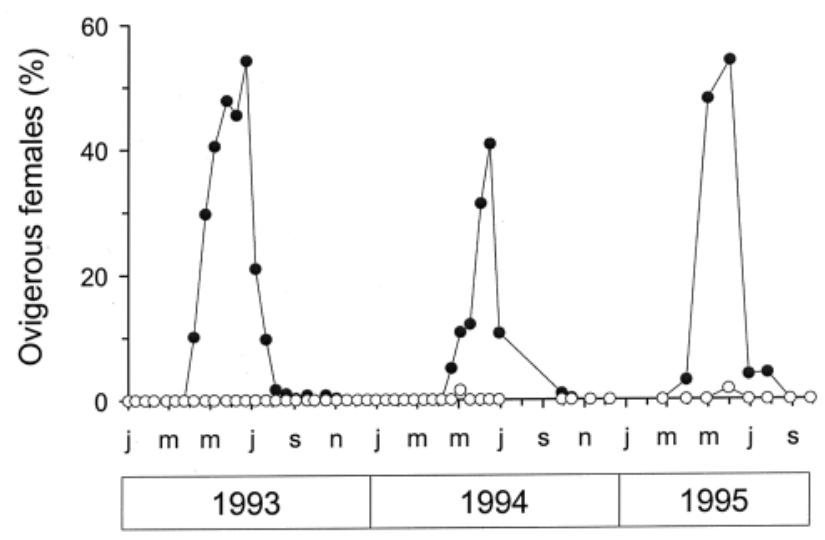

Figure 6. Temporal variation in the percentage of noninfected $(\bullet)$ and infected $(\bullet)$ reproductive females (females with brood pouches with or without eggs) relative to all adult females of Cyathura from the sandflat-site in Mondego Estuary.

\section{Temporal patterns of first intermediate host and definitive host}

To understand spatial and temporal patterns of cysts in Cyathura, the phenology of the first intermediate and definitive hosts is important. The numbers of waders (definitive host) were highest during the winter months (November to February), due to the importance of the Mondego Estuary as a wintering ground for many migratory wader species, in particular the Dunlin Calidris alpina and the Avocet Recurvirostra avosetta (Figure 7). Smaller peaks occurred during Spring (April to May) and Autumn migration (August to September).

Hydrobia (first intermediate host) densities were different between the two study sites. At the Zostera-site, Hydrobia reached densities of nearly 300000 ind $\mathrm{m}^{-2}$, but this was mainly due to the occurrence of high numbers of small recruits (Cardoso et al., 2002). Generally, the density of snails $\geqslant 2 \mathrm{~mm}$ (Figure 8) fluctuated around 63000 ind $\mathrm{m}^{-2}$ at this site, whereas the adult density $(\geqslant 2 \mathrm{~mm})$ on the sandflat rarely exceeded 7000 ind $\mathrm{m}^{-2}$. Nevertheless, the population reached nearly 135000 ind $\mathrm{m}^{-2}$ in March 1993 concomitantly with a bloom of green macroalgae.

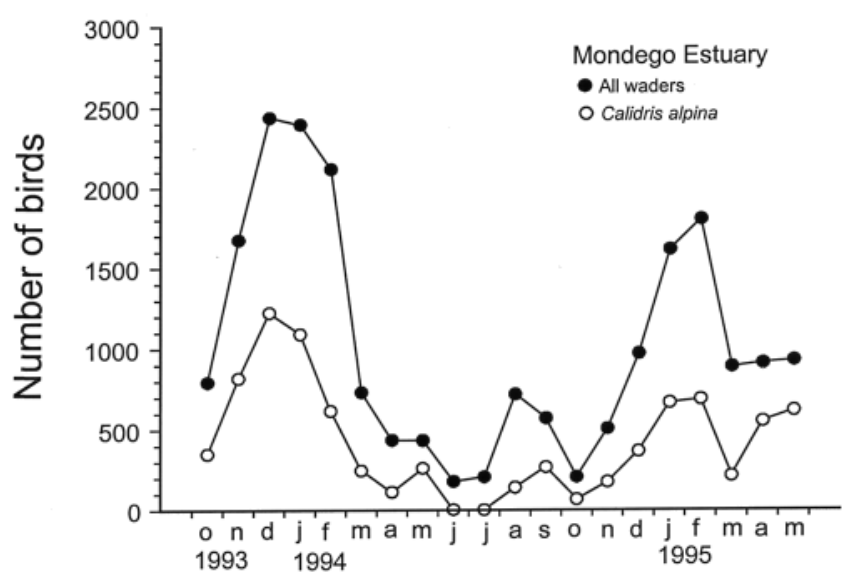

Figure 7. Monthly variation in abundance of all waders and Dunlins (Calidris alpina) in Mondego Estuary (October 1993May 1995). Data reproduced with permission from Múrias et al. 1997. 


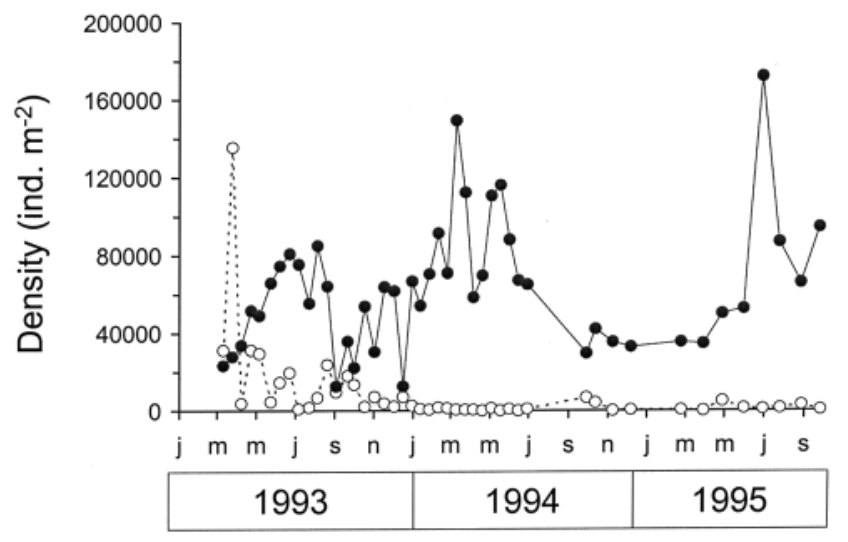

Figure 8. Temporal variation in density $\left(\right.$ ind $\mathrm{m}^{-2}$ ) of Hydrobia (shell length $\geqslant 2 \mathrm{~mm}$ ) at the sandflat-site $(\bullet)$ and at the Zostera-site (•) in Mondego Estuary from March 1993 until October 1995 (data provided by Lillebø et al. (1999) and Cardoso et al. (2002)).

\section{DISCUSSION}

\section{Trematodes in Cyathura}

The present study shows the dominance of cysts from at least two microphallid species in Cyathura: M. subdolum and Levinseniella sp. The presence of these two species has been verified from DNA-studies of cysts taken from Cyathura in 2001 (Warberg, 2003). In addition, we found M. claviformis in Hydrobia specimens collected in 2001 in the Mondego Estuary. This species can also be expected to account for Author: a fraction of the cysts recovered from Cyathura as recent ${ }_{\text {col } 1}$ expese experiments have indicated that all the mentioned micropersonal phallids are able to infect Cyathura (personal observation).

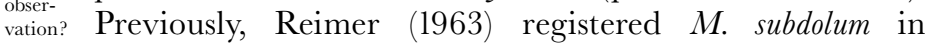
Cyathura from the Baltic Sea. Schulenburg et al. (1999) have reported the presence of unidentified microphallid species in Cyathura, from different European localities, using DNA-techniques.

The present paper provides the first data of the unknown trematode Levinseniella sp. It is remarkable that Levinseniella is quantitatively dominant to M. subdolum in Cyathura because, in 2001, more Hydrobia specimens from the estuary were infected with either $M$. subdolum or M. claviformis than with Levinseniella (a factor of 11). Furthermore, snails infected with $M$. subdolum have a much higher shedding rate of cercariae than snails infected with Levinseniella (personal observation). In addition, the latter has a longer development time in Cyathura (3 wks vs 5-6 wks) (Galaktionov et al., 1997; Damsgaard, 2002; personal observation). New recordings of infections in Cyathura from the Mondego Estuary, in 2001 have confirmed the dominance of Levinseniella over M. subdolum cysts.

To generate the prevalence pattern of the two species, some selective mechanisms may be involved. Of course, it is possible that other amphipods or isopods from the estuary have another infection profile, with $M$. subdolum being dominant, as this would contribute to an understanding of the patterns within snails. Other potential crustacean hosts do occur in the estuary (Marques et. al., 2002). However, this will not explain the pattern in
Cyathura, as we can expect specimens to be exposed to more infective propagules of $M$. subdolum than of Levinseniella. Therefore, it suggests that Levinseniella exhibit specific adaptations to infect Cyathura. Levinseniella cercariae are tailless and do not swim. They stick to the bottom, where they move slowly around in a leech-like manner. In contrast, $M$. subdolum larvae swim in the water layer, close to the bottom. Therefore, we propose that Levinseniella is better adapted behaviourally than M. subdolum to infect a sluggish mud-dwelling isopod such as Cyathura. But functional differences in penetration capability of cercariae of the two species, such as shape and size of stylets, could also be important in explaining host specificity.

\section{Prevalence and intensity patterns}

Although there are interannual and inter-site differences, the microphallid infections in Cyathura generally peak in autumn and winter months. This temporal pattern is associated with the phenology of waders that primarily are using the estuary as a wintering area. As Cyathura is prey to dunlins, and other waders (Kentish, ringed and grey plovers) (Múrias, personal observation), their presence will promote dispersal of trematode eggs. As a consequence, the development of infections in the Hydrobia population will be closely coupled with the increase in bird numbers. At present, we do not have data showing the phenology of infections in Hydrobia, but we expect a peak in the prevalence pattern of snails a few weeks after the peak occurrence of waders. Generally, an increase in shedding rates and a decline in maturation time can be expected, following the temperature rise from March-April to mid-summer (Lillebø et al., 1999). Until November-December, where the temperature is still around $14-16^{\circ} \mathrm{C}$, there will be a potential for cercariae production, if the temperature-dependent shedding rate of the unknown Levinseniella follows the pattern observed for other microphallids (Mouritsen \& Jensen, 1997). The number of infected snails will limit the total production of cercariae. The prevalence of infections in snails will not be expected to increase until the arrival of migratory birds from October onwards. Given a development time of a few weeks, from ingested parasite eggs to cercariae, there will be a relatively short period in October-December, with rising bird numbers and an appropriate temperature, where supplies of cercariae can increase again. Several factors may contribute to the patterns of microphallid cysts in Cyathura. The pattern is a result of the balance between supplies of larval propagules shed from snails and the removal of infected Cyathura specimens from the population through different mortality agents.

To explain the difference in prevalence in Cyathura between sites in the Mondego Estuary, the density of infected Hydrobia specimens, in particular, is supposed to be important. The density of snails is generally high on the studied sites, but the stock from the sandflat is strongly dominated by juveniles, in contrast to those from the Zostera-site. As snails smaller than $2 \mathrm{~mm}$ (shell height) do not host microphallids (Probst \& Kube, 1999), it is obvious that the Zostera site potentially could accommodate more infected snails than the sandflat site. Except for a short period in 1993, the abundance of snails on the sandflat 
being larger than $2 \mathrm{~mm}$ is less than 7000 ind $\mathrm{m}^{-2}$ (Cardoso et al., 2002). Apart from snails, there could also be environmental factors that may reduce transmission rates between snails and isopods.

Microphallids have been shown to cause mortality among heavily infected specimens of Corophium volutator (Pallas) (Muus, 1967; Mouritsen \& Jensen, 1997). It has also been demonstrated that surface activity in Corophium is promoted by parasites, probably because heavily infected specimens may have difficulty swimming and making burrows (Damsgaard, 2002). Such surface active specimens are exposed to mortality agents, such as predators, and unfavourable abiotic factors. Actually, the observed decline in maximum cyst intensity for Cyathura, with a body length above $7 \mathrm{~mm}$, could be a result of such mortality. The presence of an upper limit for the cyst number, as indicated by the formula for MCN, could also be a result of parasite induced host mortality at high cyst intensities. Because of space limitation inside the body of Cyathura, there is an upper limit to the number of large cysts that a specimen can accommodate. Along a $2 \mathrm{~mm}$ Cyathura body, there can be 6 mature cysts (each $340 \mu \mathrm{m}$ ) in a row. So, to approach the maximum numbers (15 cysts for a length increase of $2 \mathrm{~mm}$ ), there should be two parallel rows. Undoubtedly, such a number of cysts will damage host tissue and will probably interfere negatively with host functioning (respiration, locomotion, behaviour).

Our data suggest that microphallids could have negative impact on offspring production, as we found microphallid cysts significantly underrepresented among ovigerous females of Cyathura. Decreased reproduction of crustaceans, following microphallid infections, has previously been reported (Muus, 1967; Bick, 1994; Thomas et al., 1995). Perhaps, the most likely explanation of ovigerous females being underrepresented among the infected individuals is that infections interfere negatively with ecdysis and gametogenesis (Muus, 1967; Thomas et al., 1995). Only those able to resist infective propagules may reproduce. Naturally, this could have significant impact on population development in infected areas. Our results suggest that microphallid cysts are responsible for the low recruitment on the Zostera site as only few ovigerous females were registered at this site. Experimental results with Cyathura have furthermore shown that even few microphallid infections may have strong negative impact on reproduction of Cyathura (personal observation). Therefore, we hypothesize that microphallids contribute to the low offspring production and weak recruitment of Cyathura at the Zostera-bed. As Cyathura is a mud-dwelling isopod with direct development, recruitment success depends on local offspring production. Consequently, recruitment failure can have long lasting consequences, as recolonization of a site must await immigrants from elsewhere. Thus population development may be controlled by microphallids influencing the reproductive capability of their hosts, and they may further induce population fragmentation. Hidden as they are inside their host, such trematodes are often ignored in field studies examining the impact of environmental factors on target species. The present results suggest that trematodes in Cyathura potentially may be cryptic determinants of its population dynamics. It is therefore recommended that parasites are included in population studies of estuarine crustaceans known to host microphallid trematodes.

This study was supported by a grant to S.M. Ferreira from FCT (Portuguese Foundation for Science and Technology, (SFRH/BD/5392/2001)) and to K. Thomas Jensen from the Carlsberg Foundation. We would like to acknowledge three anonymous referees for their constructive comments.

\section{REFERENGES}

Bick, A., 1994. Corophium volutator (Corophiidae: Amphipoda) as an intermediate host of larval digenea - an ecological analysis in a coastal region of the southern Baltic. Ophelia, 40, 27-36.

Cardoso, P.G., Lillebø, A.I., Pardal, M.A., Ferreira, S.M. \& Marques, J.C., 2002. The effect of different primary producers on Hydrobia ulvae population dynamics: a case study in a temperate intertidal estuary. Fournal of Experimental Marine Biology and Ecology, 277, 173-195.

Damsgaard, J.T., 2002. Transmissionseffektivitet og vertseffekter af microphallide trematod-arter $i$ relation til Corophium volutator. MSc thesis, University of Aarhus, Aarhus, Denmark.

Deblock, S., 1980. Inventaire des trématodes larvaires parasites des mollusques Hydrobia (Prosobranches) dés côtes de France. Parassitologia, 22, 1-105.

Galaktionov, K.V., Malkova, I.I, Irwin, S.W.B., Saville, D.H. \& Maguire, J.G., 1997. The structure and formation of metacercarial cysts in the trematode family Microphallidae Travassos 1920. Journal of Helminthology, 71, 13-20.

Lillebø, A.I.B. (1996). Estrutura populacional, dinâmica e produção de Hydrobia ulvae (Pennant) (Mollusca: Prosobranchia) ao longo de um gradiente de eutrofização no estuário do Mondego (Portugal). MSc thesis, Universidade de Coimbra, Coimbra, Portugal.

Lillebø, A.I., Pardal, M.A. \& Marques, J.C., 1999. Population structure, dynamics and production of Hydrobia ulvae (Pennant, 1777) (Mollusca: Prosobranchia) along an eutrophication gradient in the Mondego estuary (Portugal). Acta Oecologica, 20, 289-304.

Lopes, R., Cabral, J.A., Múrias, T., Pacheco, C. \& Marques, J.C., 2002. Status and habitat use of waders in the Mondego estuary. In Aquatic ecology of the Mondego River basin-global importance of local experience (ed. M.A Pardal, J.C. Marques and M.A. Graça), pp. 219-230. Coimbra: Imprensa da Universidade.

Marques, J.C., Martins, I., Teles-Ferreira, C. \& Cruz, S., 1994. Population dynamics, life history, and production of Cyathura carinata (Krøyer) (Isopoda: Anthuridae) in the Mondego estuary, Portugal. Fournal of Crustacean Biology, 14, 258-272.

Marques, J.C., M.A. Pardal \& P. Maranhão, 2002. Characterisation of the macroinvertebrate benthic communities in the Mondego Estuary. In Aquatic ecology of the Mondego River Basin-global importance of local experience (ed. M.A Pardal, J.C. Marques and M.A. Graça), pp. 169-197. Coimbra: Imprensa da Universidade.

Mouritsen, K.N. \& Jensen, K.T., 1997. Parasite transmission between soft-bottom invertebrates: temperature mediated infection rates and mortality in Corophium volutator. Marine Ecology Progress Series, 151, 123-134.

Mouritsen, K. \& Poulin, R., 2002. Parasitism, community structure and biodiversity in intertidal ecosystems. Parasitology, 124, 101-117.

Múrias, T., Cabral, J. A., Lopes, R.J. \& Marques, J.C., 1997. Low-water use of the Mondego estuary (west Portugal) by waders (Charadrii). Ardeola, 44, 79-91.

Muus, B., 1967. The fauna of Danish estuaries and lagoons. Distribution and ecology of dominating species in the shallow reaches of the mesohaline zone. Meddelelser fra Danmarks Fiskeri og Havundersøgelser, 5, 1-316. 
Probst, S. \& Kube, J., 1999. Histopathological effects of larval trematode infections in mudsnails and their impact on host growth: what causes gigantism in Hydrobia ventrosa (Gastropoda: Prosobranchia)? Journal of Experimental Marine Biology and Ecology, 238, 49-68.

Rebecq, J., 1964. Recherches systématiques, biologiques et écologiques sur les formes larvaires de quelques trématodes de Camargue. Thèse de Doctorat d'état. Faculté des Sciences de Marseille, Marseille, France.

Reimer, L., 1963. Zur Verbreitung der Adulti und Larvestadien der Familie Microphallidae VIANA, 1924 (Trematoda, Digenea) in der Mittleren Ostsee. Zeitschrift für Parasitenkunde, 23, 253-273
Schulenburg, J.H.G., English, U. \& Wägele, J.W., 1999. Evolution of ITS1 rDNA in the Digenea (Platyhelminthes: Trematoda): 3 ' end sequence conservation and its phylogenetic utility. Fournal of Molecular Evolution, 48, 2-12.

Thomas, F., Renaud, F., Derothe, J.M., Lambert, A., Meeüs, T. De \& Cézilly, F., 1995. Assortative pairing in Gammarus insensibilis (Amphipoda) infected by a trematode parasite. Oecologia, 104, 259-264.

Warberg, R., 2003. ITS sekvensdata og morfologiske karakterer anvendt til identifikation af arter indenfor familien Microphallidae (Trematoda: Digenea). MSc thesis, University of Aarhus, Aarhus, Denmark.

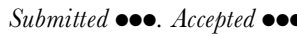

